\title{
Widespread Occurrence and Low Genetic Diversity of Colombian datura virus in Brugmansia Suggest an Anthropogenic Role in Virus Selection and Spread
}

Dan O. Chellemi and Craig G. Webster, United States Department of Agriculture, Agricultural Research Service (USDA-ARS), Fort Pierce, FL 34945; Carlye A. Baker and Mani Annamalai, Florida Department of Agriculture and Consumer Services, Division of Plant Industry, Gainesville, FL 32614; Diann Achor, University of Florida, Citrus Research and Education Center, Lake Alfred, FL 33850; and Scott Adkins, USDA-ARS, Fort Pierce, FL 34945

\begin{abstract}
Chellemi, D. O., Webster, C. G., Baker, C. A., Annamalai, M., Achor, D., and Adkins, S. 2011. Widespread occurrence and low genetic diversity of Colombian datura virus in Brugmansia suggest an anthropogenic role in virus selection and spread. Plant Dis. 95:755-761.

Brugmansia (Brugmansia spp.) is a perennial shrub in the Solanaceae, originating from South America, that is a popular landscape plant in the tropics and subtropics and container plant in temperate regions. Virus-like symptoms including mosaic, rugosity, and faint chlorotic spots were first observed on leaves of Brugmansia plants in a south Florida nursery in November 2003. Colombian datura virus (CDV) was identified in these initial plants and subsequent Brugmansia and Datura metel (a Brugmansia relative also grown as an ornamental) plants obtained from Florida, Connecticut, Wisconsin, and California. Overall, $77.5 \%$ of Brugmansia and two of four D. metel plants tested

were infected with CDV. Partial NIb/CP sequences of 28 Brugmansia $\mathrm{CDV}$ isolates from this study were compared with all $16 \mathrm{CDV}$ isolates in GenBank and found to share high levels of nucleotide and amino acid identity, with negative selection estimated to be occurring. A single Brugmansia plant was also infected with a recently described tobamovirus. The low genetic diversity of CDV observed, along with negative selection pressure on $\mathrm{NIb} / \mathrm{CP}$, suggests a recent ancestry ( $<400$ years) of the worldwide population of CDV, coinciding with anthropogenic collection and dissemination of Brugmansia plants from their center of origin.
\end{abstract}

Brugmansia (Brugmansia spp.), also known as Angel's trumpet, is a solanaceous ornamental that produces large, fragrant, and attractive flowers. Seven wild Brugmansia species can be differentiated $(3,32)$, all native to either the lowland tropical or Andes mountain regions of South America. Additionally, several multiplespecies hybrids exist in the wild without intentional anthropogenic pollination, including B. $\times$ candida (B. aurea $\times$ B. versicolor) $(28)$. In its native habitat, Brugmansia are semi-woody perennial trees or shrubs distinguishable from members of the closely related genus Datura by growth pattern, and fruit and seed morphology. All Brugmansia species contain high concentrations of alkaloids including atropine, hyoscyamine, and hyoscine (7), and it is for this reason that it has been cultivated, traded, and used for centuries by native South Americans for ceremonial and cultural purposes $(7,29)$.

In the more temperate climates of North America, Europe, and Asia, Brugmansia species have become widely popular (following their introduction during colonial times) among botanists, gardeners, and plant collectors as large container specimens due to the vast array of flower shapes, colors, and scents (Fig. 1). Brugmansia is highly valued by amateur and commercial plant breeders because of the ease of hybridization between different species, and the simplicity with which it can be vegetatively propagated and

\section{Corresponding author: S. Adkins, E-mail: scott.adkins@ars.usda.gov}

Mention of a trademark, warranty, proprietary product, or vendor does not constitute a guarantee by the U.S. Department of Agriculture and does not imply its approval to the exclusion of other products or vendors that also may be suitable.

* The $\boldsymbol{e}$-Xtra logo stands for "electronic extra" and indicates that Figures 1 and 2 appear in color in the online edition.

Accepted for publication 18 February 2011

doi:10.1094/PDIS-09-10-0654

This article is in the public domain and not copyrightable. It may be freely reprinted with customary crediting of the source. The American Phytopathological Society, 2011. disseminated as cuttings. Well over 200 Brugmansia cultivars, including many multiple-species hybrids, have been registered by several organizations (e.g., 1; http://www.brugmansia.us/), and plants are commonly traded or sold among Brugmansia enthusiasts around the world.

Like many solanaceous plants, Brugmansia is susceptible to infection by various viruses. As a vegetatively propagated plant, Brugmansia can become a "sink" for these viruses, which are subsequently spread by movement of plant material. Although many viruses are known to infect Brugmansia $(12,21,26,30)$, the most-studied virus is Colombian datura virus (CDV), a potyvirus initially described from Datura candida and D. sanguinea (species later reclassified as Brugmansia) samples collected in the Sibundoy Valley, Putumayo, Colombia as part of solanaceous plant taxonomic studies in the late 1960s (20). CDV was subsequently found in additional Datura (later reclassified as Brugmansia) cuttings imported from Colombia, Ecuador, and Bolivia $(21,22)$, and more recently from Brugmansia plants cultivated in Europe $(26,34)$. CDV has also been reported in Juanulloa aurantiaca and Petunia $\times$ hybrida (26). Since its initial identification from Brugmansia imported into the United States over 40 years ago, CDV had been subsequently reported only once, in a terrestrial orchid in South Carolina (15), leading many Brugmansia aficionados to consider $\mathrm{CDV}$ to no longer be present.

In November 2003, CDV was identified from several Brugmansia plants in a south Florida nursery exhibiting virus-like symptoms (Fig. 2) on the leaves, including a mosaic of light and dark green (2). Due to the increasing popularity and economic importance of Brugmansia as an ornamental crop, we initiated a broader survey for CDV and other viruses in Brugmansia and D. metel obtained from major producers in four geographically distinct regions (southeast, northeast, midwest, and west) of the United States. The genetic diversity of CDV isolates from all four regions was compared with worldwide CDV isolates to ascertain the anthropogenic role in virus dissemination.

\section{Materials and Methods}

Plant collection. Multiple cultivars of Brugmansia and D. metel were purchased from the six commercial plant nurseries recog- 
nized as the major suppliers of these species to U.S. markets, and located in four states (two each in Florida and Connecticut, one each in California and Wisconsin) during 2004 and 2005 (Table 1). Individual plants were maintained in a climate-controlled greenhouse in Fort Pierce, FL with insect control for the duration of the study. Leaf tissue was also collected from Brugmansia growing in the landscape in St. Lucie (two plants), Broward (one plant), and Dade (four plants) counties in Florida between 2005 and 2008.

Virus detection by serology. Leaf tissue was assayed for viruses known to commonly infect solanaceous plants. Commercially available enzyme-linked immunosorbent assays (ELISA) were used according to the manufacturer's instructions (Agdia Inc., Elkhart, IN, and Bioreba, Reinbach, Switzerland) for detection of potyviruses, Tobacco mosaic virus (TMV) and related tobamoviruses, Cucumber mosaic virus (CMV), and Tomato spotted wilt virus (TSWV) and related tospoviruses. Reverse transcriptionpolymerase chain reaction (RT-PCR) with total RNA extracts (RNeasy Plant Mini Kit, Qiagen, Valencia, CA) from leaves was used to confirm ELISA-positive samples as described below.

Detection of potyviruses by RT-PCR. For an initial set of clones from the November 2003 plants, first-strand cDNA was synthesized from total plant RNA by Moloney murine leukemia virus (MMLV) reverse transcriptase (Promega Corp., Madison, WI) at $42^{\circ} \mathrm{C}$ for 45 min with standard methods (35) using a previously described potyvirus $3^{\prime}$ terminus primer (M4T; 10). The $3^{\prime}$ terminus of the genome (including partial NIb gene, entire coat protein $[\mathrm{CP}]$ gene, and 3' UTR sequences) was amplified by PCR using the previously described degenerate potyvirus Sprimer and $3^{\prime}$ terminus M4 primer (10) by 30 cycles with $\mathrm{Taq}$ polymerase (Promega) at $94^{\circ} \mathrm{C}$ for $30 \mathrm{~s}, 47^{\circ} \mathrm{C}$ for $2 \mathrm{~min}$, and $72^{\circ} \mathrm{C}$ for $2 \mathrm{~min}$. The predicted length of the amplified DNA product was $\sim 1,700 \mathrm{bp}$. All PCR products were ligated into pGEM-T (Promega). Ten clones per sample were sequenced on an ABI3730XL automated sequencer at the USHRL DNA Sequencing Support Laboratory.

Sequence analysis of all initial clones revealed CDV as the only potyvirus present in ELISA-positive samples. Consequently, a second pair of primers was designed from the first CDV sequences obtained (GenBank accession AY621656) and used for all subsequent RT-PCR analysis. First strand cDNA was synthesized from total plant RNA by MMLV reverse transcriptase at $50^{\circ} \mathrm{C}$ for $45 \mathrm{~min}$ with standard methods (35) using a second previously described degenerate potyvirus $3^{\prime}$ terminus primer (17). Partial NIb/CP genes were amplified with $\mathrm{CDV}$ primers $\mathrm{CDVv}$ (5'-GGG AGAGCTCCTTACCTAGC- $\left.3^{\prime}\right)$ and CDVve (5'-CCATGTATG TTTGGTGATGTACC-3') by 30 cycles with Taq polymerase (Promega) at $94^{\circ} \mathrm{C}$ for $30 \mathrm{~s}, 55^{\circ} \mathrm{C}$ for $45 \mathrm{~s}$, and $72^{\circ} \mathrm{C}$ for $1 \mathrm{~min}$. The predicted length of the amplified product was $511 \mathrm{bp}$ (without primers). These PCR products were also ligated into pGEM-T, and 10 clones per sample were sequenced as described above.

Detection of tobamovirus by RT-PCR. For tobamovirus confirmation, first strand cDNA was synthesized from total plant RNA by MMLV reverse transcriptase at $50^{\circ} \mathrm{C}$ for $45 \mathrm{~min}$ with standard methods (35) using random hexamers. A 258-bp portion of the $\mathrm{CP}$ gene was amplified by PCR using a mixture of degenerate solanaceous tobamovirus viral sense primers SolACPv (5'-GAACTT WCAGAAGMAGTYGTTGATGAGTT-3') and SolBCPv (5'-GAA
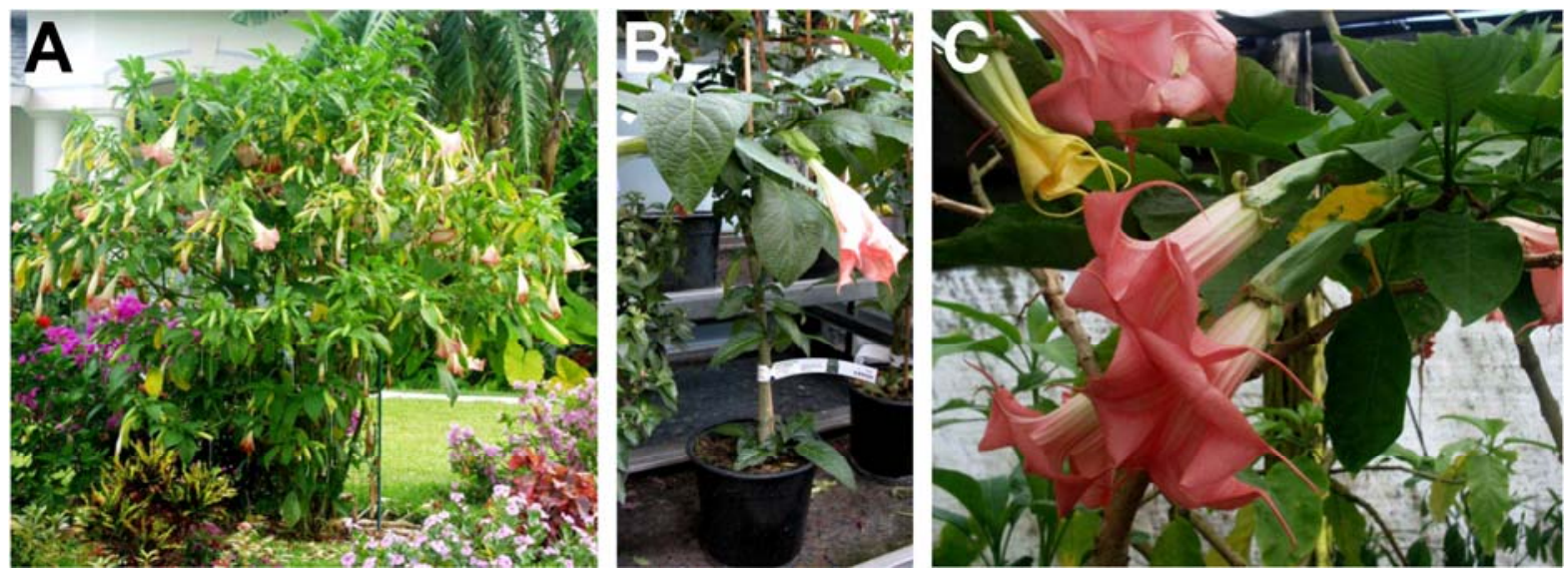

Fig. 1. Brugmansia is a popular flowering plant in many parts of the world. It is commonly grown as A, a landscape plant in the tropics and subtropics and B, a container plant in temperate regions. C, Brugmansia has fragrant, trumpet-shaped flowers of varying colors, sizes, and scents.
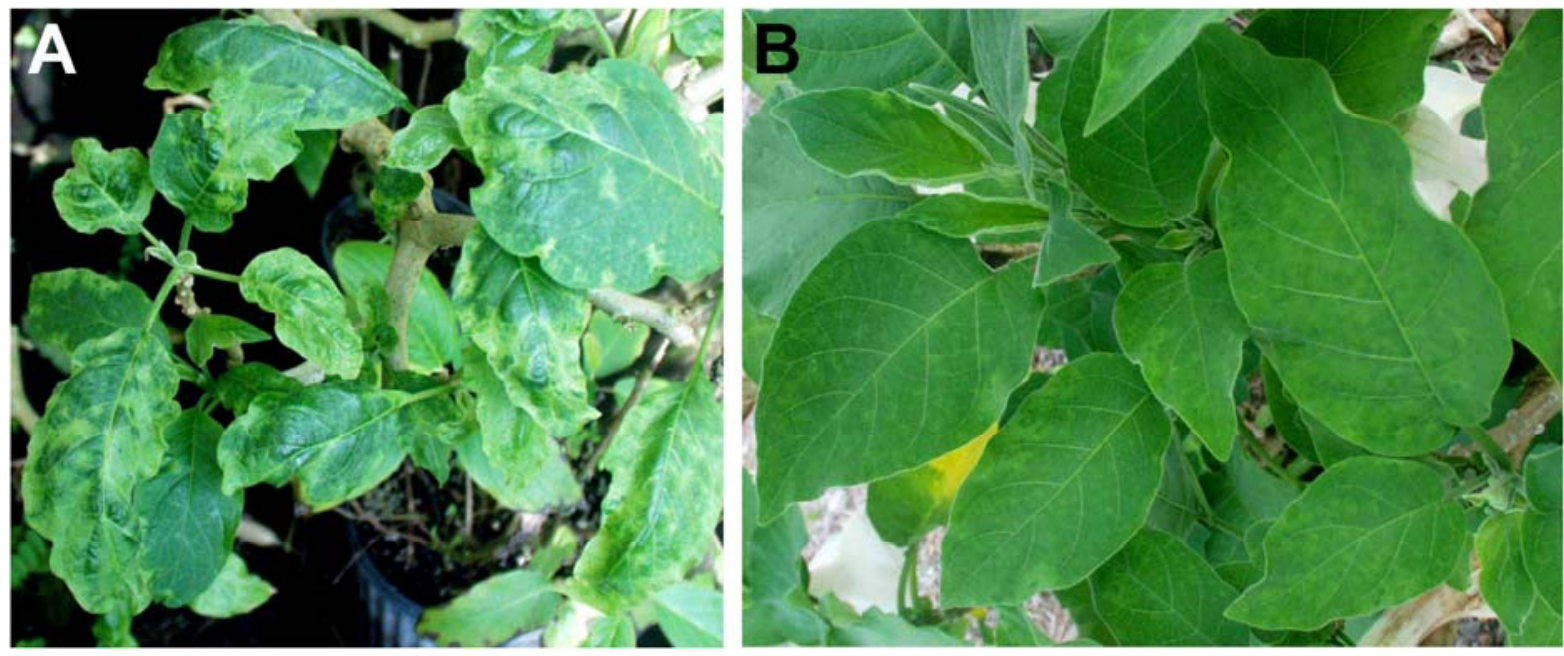

Fig. 2. Virus-like symptoms were commonly observed in Brugmansia nursery and landscape plants. Symptoms included A, mosaic and rugosity and B, faint chlorotic spots. 
CTCACTGARRMRGTTGTTGAKGAGTT-3'), and viral complementary sense primers SolACPvc $\left(5^{\prime}\right.$-CCCTTCGATTTAAGT GGAGGGAAAAAC-3') and SolBCPvc (5'-CGTTTMKATTYA AGTGGASGRAHAAMCACT-3'). These primers were designed as part of this study from CP sequences (available in GenBank in April 2003) of TMV, Tomato mosaic virus, Obuda pepper virus, Odontoglossum ringspot virus, Paprika mild mottle virus, Pepper mild mottle virus, and Tobacco mild green mosaic virus (TMGMV) to enable RT-PCR amplification of all solanaceous plant-infecting tobamoviruses known at that time. This PCR product was ligated into pGEM-T, and clones were sequenced as described above.

Pospiviroid testing. Given recent reports of pospiviroid infections of Brugmansia and other solanaceous ornamentals in Europe (45-47), we used previously reported universal pospiviroid primers (Pospi1-RE and Pospi1-FW; 48) and conditions for RT-PCR analysis of the 39 Brugmansia plants from nurseries 2 to 6 . First strand cDNA was synthesized from total plant RNA by MMLV reverse transcriptase at $45^{\circ} \mathrm{C}$ for 45 min with standard methods (35) using random hexamers. Citrus tissue infected with Citrus exocortis viroid $(\mathrm{CEVd})$ was used as a positive control.

Isolation and characterization of virions of a Florida Brugmansia CDV isolate. Virions of the Florida CDV isolate collected in November 2003 were isolated essentially as described by Nelson and colleagues (31) from leaves of Nicotiana tabacum 'Xanthi nc' plants mechanically inoculated with CDV-infected Brugmansia leaves homogenized in $20 \mathrm{mM}$ sodium phosphate buffer $(\mathrm{pH}$ 7.0) containing $0.1 \%(\mathrm{wt} / \mathrm{vol})$ sodium sulfite and $1 \%(\mathrm{wt} / \mathrm{vol})$ Celite. Partially purified virion preparations were analyzed on 200 mesh Formvar-coated copper grids and stained with $2 \%$ (wt/vol) aq. uranyl acetate. Measurements of 33 particles representative of the Florida CDV isolate were used to determine a mean particle length.
Leaf strips for light microscopy were prepared according to Christie and Edwardson (11). Epidermal strips were removed from the underside of Brugmansia leaves and put into a $5 \%$ ( $\mathrm{vol} / \mathrm{vol})$ solution of Triton X-100 to remove plastids. This was followed by staining in Calcomine Orange and Luxol Brilliant Green (OG). After 10 to $15 \mathrm{~min}$ in the stain, the tissue was destained and mounted on slides in Euparal. The slides were viewed on a light microscope for the presence or absence of viral inclusion bodies.

An experimental host range for the partially purified Florida $\mathrm{CDV}$ isolate was determined by mechanical inoculation of 12 species in three families (Table 2). All experimental hosts were grown from seed (except Solanum bahamense, which was propagated by cuttings from a virus-free stock plant) and maintained in an airconditioned greenhouse under natural lighting with a daytime high temperature of $30^{\circ} \mathrm{C}$. All plants (5 to 10 per species) were mechanically inoculated at the 3 to 4 true leaf stage with partially purified CDV virions using the phosphate-sulfite buffer indicated above. Plants were evaluated weekly for symptoms. Local and systemic CDV infection of inoculated plants was confirmed by one or more of the following methods: (i) commercially available potyvirus ELISA (as described above; Agdia); (ii) RT-PCR with CDV primers (as described above); and/or (iii) inoculation of $N$. $t a-$ bacum 'Xanthi nc' with either washed, inoculated or upper, noninoculated leaves, respectively, homogenized in the phosphatesulfite buffer indicated above followed by evaluation of etch symptoms 14 days later.

Sequence analysis of Brugmansia CDV isolates. Partial $\mathrm{NIb} / \mathrm{CP}$ gene sequences of 28 Brugmansia CDV isolates determined in this study (AY621656 and HQ223421-HQ223447) were compared with the corresponding region of all $16 \mathrm{CDV}$ sequences available in GenBank (AB179622, AF030689, AJ237921AJ237923, AJ437482, AM113754-AM113761, EU363481, and

Table 1. Viruses detected in Brugmansia plants from commercial nurseries

\begin{tabular}{|c|c|c|c|c|c|c|c|c|}
\hline Nursery & State & $\begin{array}{l}\text { Brugmansia } \\
\text { plants }\end{array}$ & Dates collected & $\begin{array}{c}\text { Potyvirus } \\
(\text { CDV })^{\mathrm{a}}\end{array}$ & $\begin{array}{c}\text { Tobamovirus } \\
\text { (BMMV) }\end{array}$ & CMV & Tospovirus & Pospiviroid \\
\hline 1 & Florida & 34 & $5 / 2004$ & 29 & 1 & 0 & 0 & $\mathrm{nt}^{\mathrm{b}}$ \\
\hline 2 & Florida & 6 & $4 / 2005,6 / 2005$ & 5 & 0 & 0 & 0 & 0 \\
\hline 3 & Connecticut & 6 & $4 / 2005$ & 5 & 0 & 0 & 0 & 0 \\
\hline 4 & Connecticut & 11 & $5 / 2005$ & 9 & 0 & 0 & 0 & 0 \\
\hline 5 & Wisconsin & 1 & $4 / 2005$ & 1 & 0 & 0 & 0 & 0 \\
\hline 6 & California & 15 & $6 / 2005$ & 11 & 0 & 0 & 0 & 0 \\
\hline Total & & 73 & & $60(82 \%)$ & $1(1 \%)$ & 0 & 0 & 0 \\
\hline
\end{tabular}

${ }^{a}$ Brugmansia plants tested by enzyme-linked immunosorbent assay (ELISA) and/or reverse transcription-polymerase chain reaction for the following viruses: Colombian datura virus $=\mathrm{CDV} ;$ Brugmansia mild mottle virus $=\mathrm{BMMV} ;$ Cucumber mosaic virus $=\mathrm{CMV}$.

${ }^{\mathrm{b}}$ Not tested $=$ nt.

Table 2. Experimental host range and symptoms of Florida Brugmansia isolate of Colombian datura virus

\begin{tabular}{|c|c|c|c|}
\hline Family ${ }^{\mathbf{a}}$ & Species & Common name & Symptoms $^{b}$ \\
\hline Asteraceae & Emilia sonchifolia & Red tassel flower & $-1-$ \\
\hline \multirow[t]{2}{*}{ Cucurbitaceae } & Citrullus lanatus 'Crimson Sweet' & Watermelon & $-1-$ \\
\hline & Cucurbita pepo 'Prelude II' & Squash & $-1-$ \\
\hline \multirow[t]{11}{*}{ Solanaceae } & Capsicum аппиит 'California Wonder' & Bell pepper & $-1-$ \\
\hline & Capsicum anпиит 'Capistrano' & Bell pepper & $-1-$ \\
\hline & Datura metel & Downy thorn-apple & E,NLL/LD,M \\
\hline & Datura stramonium & Jimsonweed & $-1-$ \\
\hline & Nicotiana benthamiana & & $\mathrm{NS} / \mathrm{LD}$ \\
\hline & Nicotiana tabacum 'Xanthi nc' & Tobacco & $\mathrm{E} / \mathrm{E}$ \\
\hline & Petunia $\times$ hybrida & Petunia & $\mathrm{NS} / \mathrm{LD}, \mathrm{M}$ \\
\hline & Solanum americanum & American black nightshade & CLL/NS \\
\hline & Solanum bahamense & Key West nightshade & $-1-$ \\
\hline & Solanum lycopersicum 'Florida 47 ' & Tomato & NLL/NS \\
\hline & Solanum viarum & Tropical soda apple & $-1-$ \\
\hline
\end{tabular}

\footnotetext{
a Family and species names according to Brako et al. (6) and USDA, NRCS (44).

${ }^{\mathrm{b}}$ Symptoms on inoculated leaves and upper noninoculated leaves indicated to left and right of slash, respectively. $-=$ no infection, $\mathrm{E}=\mathrm{etch}, \mathrm{NLL}=$ necrotic local lesions, $\mathrm{LD}=$ leaf deformation, $\mathrm{M}=$ mosaic, $\mathrm{NS}$ = infected but no symptoms, $\mathrm{CLL}=$ chlorotic local lesions. Local and systemic infection confirmed by (i) commercially available potyvirus enzyme-linked immunosorbent assay (Agdia, Elkhart, IN), (ii) reverse transcription-polymerase chain reaction, and/or (iii) inoculation of $N$. tabacum 'Xanthi nc' with either washed, inoculated, or upper, noninoculated leaves, respectively, homogenized in $20 \mathrm{mM}$ sodium phosphate buffer ( $\mathrm{pH}$ 7.0) containing $1 \%$ (wt/vol) Celite.
} 
EU571230). Alignments, sequence diversity, and phylogenetic reconstructions were made using MEGA 4.1 (42). Sequences were aligned using Clustal W with the default parameters, and the resulting alignment was visually inspected and trimmed to include only the 511 nucleotide (nt) region amplified with CDV primers (described above). Phylogenetic trees were constructed from the aligned sequences using both neighbor-joining and maximum parsimony methods and bootstrapped 1,000 times to determine the robustness of the groupings. Diversity of nt and amino acid (aa) sequences were calculated using a p-distance model with default conditions with standard errors estimated from 1,000 bootstrap replications. Selection pressures of individual codons within coding regions were analyzed using the Datamonkey online positive selection interface (23) available at http://www.datamonkey.org/. The ratio of non-synonymous $\left(\mathrm{d}_{\mathrm{N}}\right)$ substitutions to synonymous $\left(d_{S}\right)$ substitutions was used to determine whether selection was occurring in CDV. Negative (or purifying) selection is indicated by a ratio of $\mathrm{d}_{N} / \mathrm{d}_{\mathrm{S}}<1$, neutral selection is indicated by a ratio of $\mathrm{d}_{N} / \mathrm{d}_{\mathrm{S}}$ $=1$, and positive selection is indicated by a ratio of $d_{N} / d_{S}>1$. Three methods of detecting selection were used: single likelihood ancestor counting (SLAC), random effects likelihood (REL), and fixed effects likelihood (FEL) (24) with default conditions including the significance level.

\section{Results}

Plant collection. A total of 77 plants (many of which lacked obvious symptoms of virus infection when received) including 73 Brugmansia (Table 1) and four D. metel were obtained from the six commercial nurseries. Collectively, 43 plants representing 18 registered Brugmansia cultivars (1) were sampled. An additional 30 Brugmansia plants of unknown parentage were sampled, including seven Brugmansia plants in the south Florida landscape. The parentage of the registered Brugmansia cultivars collected were $B$. suaveolens, $B$. versicolor, $B . \times$ candida, $B$. insignis $\times B$. suaveolens hybrids and multiple-species hybrids (Table 3 ).

Incidence of viruses and viroids. The overall incidence of potyvirus infection in Brugmansia plants from the six nurseries, as detected by ELISA, was $82 \%$ (Table 1). Two of four D. metel samples were potyvirus-positive, with both infected plants occurring in the same nursery. Subsequent RT-PCR and sequence analysis identified CDV in all ELISA-positive samples. Thus, CDV was identified in $82 \%(60 / 73)$ of Brugmansia plants from nurseries, two of seven Brugmansia landscape plants from south Florida (both from St. Lucie County), and two of four D. metel plants from nurseries. A single Brugmansia nursery plant was found infected with an unknown tobamovirus that at the time was most closely related to TMGMV, and later identified as the recently described Brugmansia mild mottle virus (BMMV; 19). No CMV, tospoviruses or pospiviroids were detected in any Brugmansia (Table 1) or $D$. metel plants from nurseries, or any Brugmansia from the Florida landscape. The incidence of CDV was highest in Brugmansia containing $B$. versicolor as a parent and lowest where only $B$. suaveolens and B. insignis were parents (Table 3 ).

Isolation and characterization of virions of a Florida Brugmansia CDV isolate. In light microscopy, cylindrical inclusions typical of potyvirus infection were found in leaf epidermal cells of

Table 3. Detection of Colombian datura virus (CDV) in Brugmansia cultivars with known parentage

\begin{tabular}{lccc}
\hline Parentage & $\begin{array}{c}\text { Cultivars } \\
\text { tested }\end{array}$ & $\begin{array}{c}\text { Plants } \\
\text { tested }\end{array}$ & $\begin{array}{c}\text { CDV } \\
\text { incidence }\end{array}$ \\
\hline B. aurea $\times$ insignis $\times$ suaveolens & 4 & 12 & $12 / 12$ \\
$\quad \times$ versicolor & & & \\
B. versicolor & 3 & 7 & $7 / 7$ \\
B. $\times$ candida (aurea, versicolor) & 4 & 5 & $4 / 5$ \\
B. suaveolens & 4 & 15 & $11 / 15$ \\
B. insignis, suaveolens & 3 & 4 & $2 / 4$ \\
\hline
\end{tabular}

${ }^{a}$ Expressed as a percentage of the number of CDV-infected plants divided by the total number of plants tested.
CDV-infected Brugmansia plants stained with OG (Fig. 3A). No cylindrical inclusions were observed in OG-stained tissue from noninfected Brugmansia. Electron microscopic examination of the partially purified Florida CDV isolate revealed flexuous rod-shaped particles (mean length of $750 \mathrm{~nm} \pm 66 \mathrm{~nm}$ ) (Fig. 3B) that were typical of those described for members of the genus Potyvirus (5).

In experiments to determine the host range of the Florida CDV isolate, no evidence of infection was detected in either of the tested Asteraceae or Cucurbitaceae species (Table 2). However, we confirmed CDV infection in six Solanaceae species, with leaf distortion, etch, mosaic, and chlorotic or necrotic local lesions being the most common symptoms observed following mechanical inoculation. No infection was detected in bell pepper, jimsonweed, Key West nightshade, or tropical soda apple.

Genetic diversity of Brugmansia CDV isolates. Sequence analysis of the cloned 3' portion of the genome of the 2003 Florida CDV isolate (GenBank accession AY621656) revealed 99\% nt identity with Hungarian and Japanese CDV isolates (GenBank accessions AJ437482 and AB179622, respectively) over a 1,644-nt region. Subsequent analysis of a 511-nt portion of the NIb/CP genes from 28 Brugmansia CDV isolates collected in this study and all $16 \mathrm{CDV}$ sequences available in GenBank indicated low genetic diversity in this region of the genome. Both nt and aa diversity were low, with a mean of $0.0100 \pm 0.0019 \mathrm{nt}$ substitutions/site and $0.0128 \pm 0.0043$ aa substitutions/site, respectively. Maximum (and mean) pairwise differences were $22 \mathrm{nt}(5.03 \pm 0.99 \mathrm{nt})$ and 7 aa $(2.13 \pm 0.73$ aa) changes over the 511 nt (170 aa) region analyzed. No significant differences in diversity of any group of CDV isolates were found, either within or between U.S. states or the rest of the world (Table 4).

A phylogenetic reconstruction of the 44 partial NIb/CP gene sequences using neighbor-joining analysis showed that while some isolates from a single state did group together (e.g., 5 of 11 Connecticut isolates), the majority were located throughout the tree and interspersed with isolates from other locations (Fig. 4). Although a large grouping of isolates from across the United States appeared, bootstrap support was not significant. Other U.S. isolates (e.g., WI1-12, CT2-16, CT1-5, and CA1-36) showed highest homology with four Hungarian CDV isolates. Maximum parsimony analysis produced a tree with very similar topology and bootstrap support (data not shown). Only four of the groupings in both methods of phylogenetic analysis had bootstrap support above the $60 \%$ cutoff used (Fig. 4 and data not shown), indicating a low level of diversity between sequences. The general absence of bootstrap support in both methods of phylogenetic analysis indicates CDV isolates did not resolve well into distinct groups and that the worldwide pop-

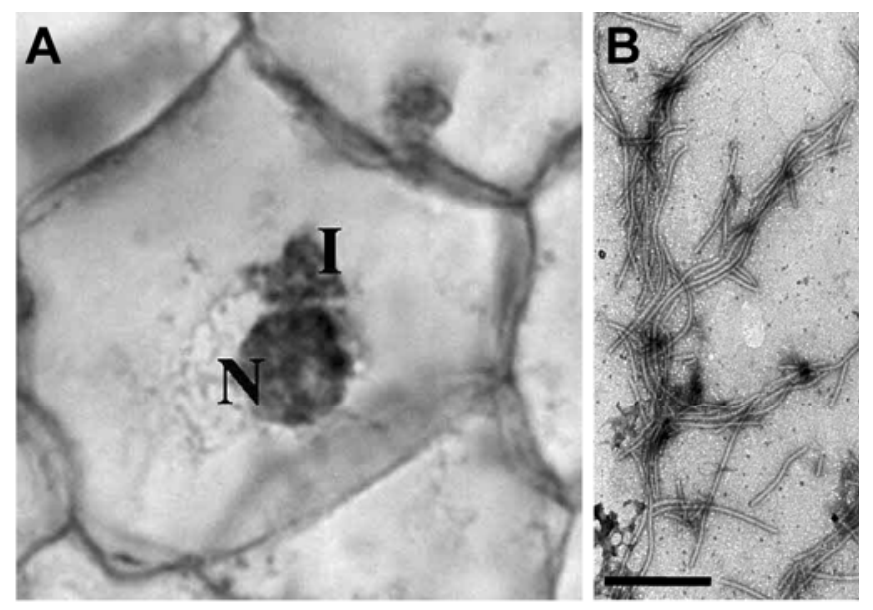

Fig. 3. Inclusion body morphology and electron microscopy confirmed the presence of a potyvirus later identified as Colombian datura virus (CDV). A, Cylindrical inclusions (I) typical of a potyvirus in Brugmansia leaf stained with orange-green protein stain. Nucleus $=\mathrm{N}$. B, Electron micrograph of partially purified virions isolated from symptomatic Nicotiana tabacum 'Xanthi nc' leaves show characteristic potyvirus morphology. Scale bar represents $500 \mathrm{~nm}$. 
ulation of CDV (for which sequence data are available) does not contain strains or variants with significantly different NIb/CP sequences.

The strength and direction of selection on the partial NIb/CP gene sequences were estimated from the $d_{N} / d_{S}$ ratio, which was 0.240 for the 511-nt portion analyzed, and thus indicates negative selection. Substitutions occurred throughout the 511 nt (170 aa) sequence with no obvious aggregation. Further evidence of negative selection in the partial $\mathrm{NIb} / \mathrm{CP}$ gene sequences was obtained from estimates for individual codons (likelihood of an individual codon being positively or negatively selected as determined by the SLAC, FEL, or REL methods indicated above) with $15.9 \%$ (27 of 170) of codons found to have $d_{N}$ significantly greater than $d_{S}$ by at least one of the three methods indicated above. Positive selection was only predicted to be occurring for two codons (1.2\%) and only by a single method (REL).

\section{Discussion}

The initial Florida Brugmansia CDV isolate from November 2003 was representative of all CDV isolates subsequently identified in this study, regardless of the geographic location, plant genus (Brugmansia or Datura), or Brugmansia cultivar from which they originated. The cylindrical inclusions observed by light microscopy in Brugmansia epidermal cells (Fig. 3A) are typical of those reported for potyviruses (11), and the flexuous rod-shaped particles of $750 \mathrm{~nm}$ observed by electron microscopy (Fig. 3B) are well within the range reported for potyviruses in general (5) and CDV in particular $(20,26,36)$. This includes Petunia flower mottle virus (13), which was isolated in the late 1990s in Europe (prior to CDV sequence data being available) and later determined to be CDV $(5,15)$. The host range and symptom expression observed for the initial Florida Brugmansia CDV isolate (Table 2) are similar but not completely identical to results reported previously for other CDV isolates $(20,36,49)$.

The mean nt and aa diversity $(0.0100$ and 0.0128 substitutions/site, respectively) of the partial NIb/CP sequence, along with the close relationship of CDV isolates from around the world, suggest an overall low level of diversity of the virus. The $5^{\prime}$ part of the $\mathrm{CP}$ coding region analyzed is known to be particularly diverse for species in the genus Potyvirus and contains the surface exposed epitopes of the CP (37), which makes the finding of such low genetic diversity surprising. This level is considerably lower than for the full CP genes of 15 other species in the genus Potyvirus, which range from 0.032 to 0.131 nt substitutions/site (9). All Brugmansia isolates of CDV analyzed in this study were collected from plants outside of the center of origin for Brugmansia. It is possible that more diverse isolates of CDV may occur in the center of origin for Brugmansia.

While grouping of isolates from one location did occur (e.g., five Connecticut isolates), overall isolates from a single state were distributed throughout the phylogenetic tree and interspersed with isolates from other U.S. states and around the world (Fig. 4). This topology was confirmed by two methods of phylogenetic reconstruction. The lack of diversification into strains suggests CDV exists as a single population of close genetic make-up, and perhaps worldwide movement of infected plant material has spread a single isolate of virus rapidly with little time for diversification to occur.

A maximum of $22 \mathrm{nt}$ changes was observed in the 511-nt CDV fragment in pairwise comparisons with a mean of $5.03 \pm 0.99$ substitutions. Assuming the rate of evolution of CDV matches other species in the genus Potyvirus at $1.1 \times 10^{-4}$ nt substitutions/site/year (18), the current level of diversity observed for CDV may have developed in $\sim 100$ to 400 years (5 to 22 substitutions :$\left.\left[1.1 \times 10^{-4} \times 511 \mathrm{nt}\right]\right)$. This time frame is in agreement with the hypothesis that collections made during colonial times were responsible for the worldwide movement of virus-infected Brugmansia and represent a genetic bottleneck for the CDV population. The apparent genetic stability of CDV since this bottleneck may be more common than expected for RNA viruses as proposed by others (16). For instance, a lack of divergence has been observed in TMGMV isolates from Nicotiana glauca (like Brugmansia, a perennial solanaceous plant) collected $\sim 100$ years apart (14) and Wheat streak mosaic virus isolates (like CDV, a species in the family Potyviridae), where the observed population diversity has arisen in approximately the last 100 years (40).

Other common plant viruses (tobamoviruses, tospoviruses, and CMV) associated with dissemination of vegetatively propagated solanaceous plant material were virtually nonexistent in the Brugmansia and $D$. metel plants we analyzed except for a single Brugmansia plant found to be infected with BMMV, a recently described tobamovirus from Brugmansia in Europe (19). The ability of the solanaceous plant-infecting tobamovirus primers designed as part of this study to detect a previously unknown virus (no BMMV sequence was available when the primers were designed) may make these primers more broadly useful for tobamovirus diagnosis. Curiously, no evidence of pospiviroid infection was found in the 39 Brugmansia samples from nurseries 2 to 6 (Table 1), although Brugmansia and other solanaceous ornamentals are increasingly being reported with pospiviroid infections in Europe (45-47).

Of the 84 Brugmansia and D. metel plants tested in this study, $76 \%$ (64 plants) were CDV infected. The high incidence of CDV contrasts sharply with the near absence of other viruses and viroids frequently associated with vegetative propagation and suggests that Brugmansia germplasm may have been infected with CDV prior to its arrival at the nurseries sampled. It is common for virus-infected Brugmansia to remain symptomless if provided with optimal nutrients and water during the summer vegetative growth period (32). Thus, infected nursery stock can remain undiagnosed due to an absence of consistent and/or obvious symptom expression, leading to unknowing dissemination of CDV-infected plants. As noted in

Table 4. Genetic diversity of Colombian datura virus (CDV) partial NIb/CP sequences

\begin{tabular}{lcccccc}
\hline & FL $^{\mathbf{a}}$ & $\mathbf{C T}$ & $\mathbf{C A}$ & WI & OR & ROW \\
\hline FL & $0.012 \pm 0.0054^{\mathrm{b}}$ & $0.012 \pm 0.0049$ & $0.0092 \pm 0.0043$ & $0.0090 \pm 0.0047$ & $0.0070 \pm 0.0033$ & $0.019 \pm 0.0055$ \\
& $0.014 \pm 0.0031$ & & & & \\
CT & $0.012 \pm 0.0025$ & $0.012 \pm 0.0049$ & $0.0093 \pm 0.0043$ & $0.0099 \pm 0.0051$ & $0.0093 \pm 0.0047$ & $0.015 \pm 0.0050$ \\
& & $0.011 \pm 0.0025$ & & & & \\
CA & $0.0084 \pm 0.0019$ & $0.0074 \pm 0.0019$ & $0.0074 \pm 0.0044$ & $0.0078 \pm 0.0051$ & $0.0054 \pm 0.0035$ & $0.014 \pm 0.0054$ \\
& & & $0.0035 \pm 0.0016$ & & $0.0060 \pm 0.0060$ & $0.0093 \pm 0.0032$ \\
WI & $0.0093 \pm 0.0025$ & $0.0076 \pm 0.0021$ & $0.0044 \pm 0.0022$ & $\mathrm{NC}^{\mathrm{c}}$ & $\mathrm{NC}$ & $0.015 \pm 0.0067$ \\
OR & $0.011 \pm 0.0031$ & $0.011 \pm 0.0034$ & $0.0064 \pm 0.0030$ & $0.0038 \pm 0.0080$ & $0.013 \pm 0.0039$ & $0.015 \pm 0.0047$ \\
ROW & $0.014 \pm 0.0027$ & $0.012 \pm 0.0022$ & $0.0090 \pm 0.0023$ & $0.0057 \pm 0.0012$ & $0.010 \pm 0.0020$ \\
\hline
\end{tabular}

${ }^{a}$ CDV isolate location abbreviations: FL, Florida; CT, Connecticut; CA, California; WI, Wisconsin; OR, Oregon; ROW, rest of world. Isolates are the same as in Figure 4 with 28 from this study and 16 from GenBank.

${ }^{b}$ Average genetic distances of CDV sequences from five U.S. states and the rest of the world as calculated by the p-value method with standard errors shown. Nucleotide (below diagonal in plain text) and amino acid (above diagonal in italics) diversity are indicated.

${ }^{\mathrm{c}} \mathrm{NC}$, not calculated (insufficient sequences available for calculating within-group diversity). 
Results, many of the plants we obtained from nurseries had no obvious symptoms of infection by a plant virus when received. Furthermore, the symptoms (including mosaic, rugosity, and faint chlorotic spots) we observed on various Brugmansia (Fig. 2) and D. metel plants were seasonal. CDV-infected Brugmansia maintained in our greenhouse showed the most obvious symptoms in spring (February to April) but during warmer months often became symptomless. This variation in and occasional lack of symptoms on the greenhouse-maintained plants is reminiscent of the original description of CDV infecting Brugmansia by Kahn and Bartels (20).

The common association of CDV and Brugmansia may be attributed to its co-evolvement with humans in the center of origin for Brugmansia spp. Both B. aurea and B. sanguinea (hosts for original CDV isolates; 20 ) are endemic to the Sibundoy Valley, a remote and isolated valley high in the Andes, and are still commonly grown there $(8,38)$. B. aurea cultivars in the Sibundoy Valley have resulted from artificial selection based upon leaf size, shape, and color because it is the leaf that is used in the ceremonial and medicinal drug preparation (29). Many of the selections have peculiar leaf characteristics that may be related to infection by a virus $(7,29)$. Bristol (7) reported that, "despite the highly conspicuous and attractive flowers of all the cultivars, the leaves are the center of interest to the natives, to whom they are the structures of economic importance." There are additional older reports of several prized Brugmansia cultivars in the Sibundoy Valley region

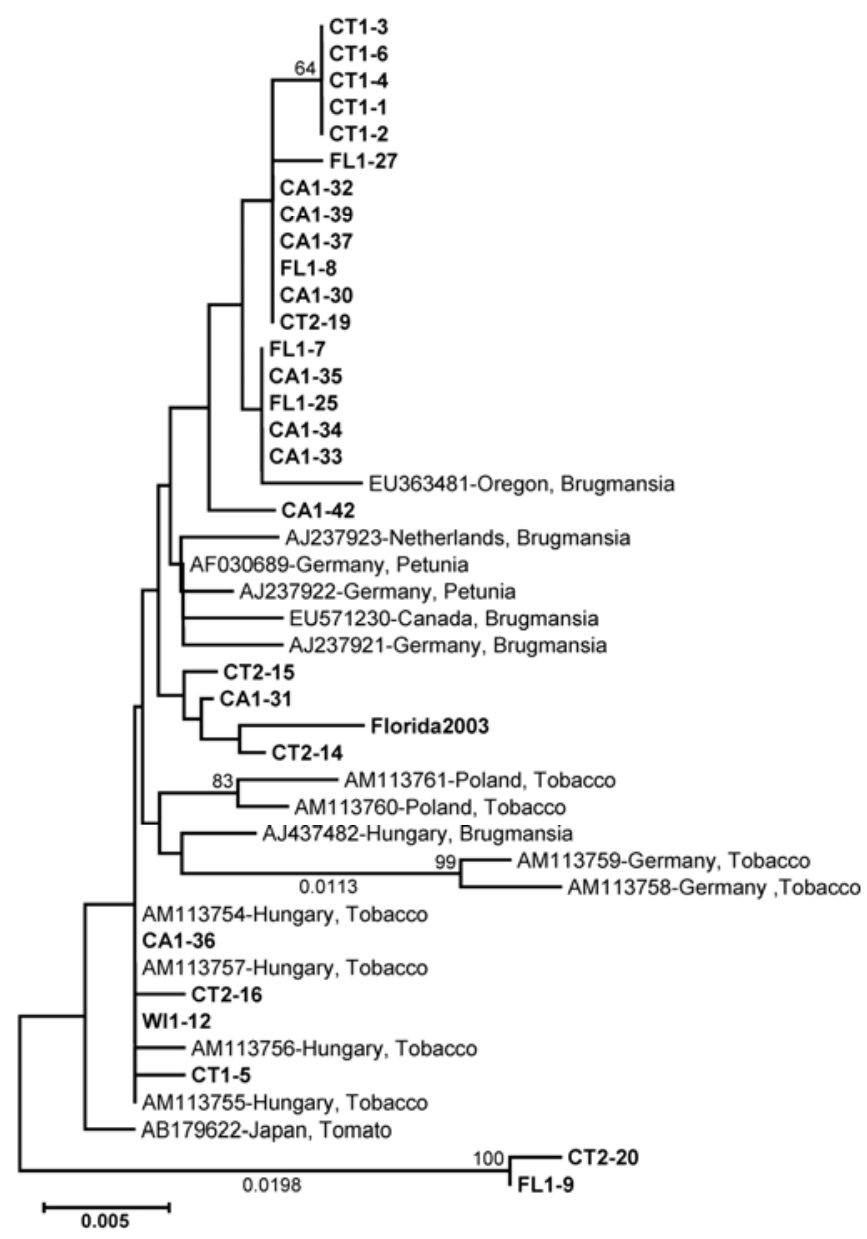

Fig. 4. Unrooted phylogenetic tree of 28 Colombian datura virus (CDV) partial $\mathrm{Nlb} / \mathrm{CP}$ nucleotide sequences from this report (bold) and corresponding region of 16 additional CDV sequences from GenBank (with accession numbers, country of origin, and host included in taxa labels). Tree was constructed using the neighborjoining method with a maximum composite likelihood nucleotide substitution model in MEGA 4.1 with default parameters. Bootstrapping (1,000 replicates) was used to infer the robustness of the groupings with values over $60 \%$ indicated at the nodes. Scale bar represents a genetic distance of 0.005 with distances greater than 0.005 indicated on the branches. with disease symptoms reminiscent of those caused by a plant virus $(4,43)$. Thus, $B$. aurea cultivars may have evolved with CDV, and the observed negative selection in the $\mathrm{NIb} / \mathrm{CP}$ gene sequences could be attributed to direct selection pressure by humans over many generations for CDV-infected plants having the most desirable phenotypic features. B. $\times$ candida (a naturally occurring hybrid) has been widely disseminated (32), and was one of the first Brugmansia types to be taken to Africa and Europe and now comprises the majority of registered Brugmansia cultivars. Thus, it is possible that CDV has been an integral component of Brugmansia culture in the New and Old Worlds since humans first began selecting plants in nature.

The impact of CDV on crops beyond Brugmansia and D. metel remains a critical area to be addressed. There are a few well-documented cases. Natural infection of greenhouse tomatoes in the Netherlands was attributed to aphid transmission of CDV from a CDV-infected Brugmansia plant that had overwintered in the same greenhouse (49). A similar situation was outlined in Germany, where CDV-infected tobacco plants found in the field were traced back to CDV-infected but symptomless Brugmansia plants overwintering in the same greenhouse where the tobacco seedlings were produced (41). Natural CDV infection of tobacco in the field has been reported in Poland, Germany, and Hungary (36). Sequence analysis showed that CDV isolates from tobacco in all three countries were closely related to each other and previously described isolates (36). Isolation of CDV from petunias in Europe as Petunia flower mottle virus (13) was likely the result of vegetative propagation of CDV-infected petunias. The report of CDV infecting the terrestrial orchid, Spiranthes cernua, obtained from a nursery in South Carolina (15) was the only other report of CDV in the United States until the time of the current study. Following our initial report of CDV-infected Brugmansia in Florida (2), CDV was also detected in Brugmansia in Oregon (GenBank accession EU363481), Canada (33), and Australia (39).

The green peach aphid (Myzus persicae), which is ubiquitous in most southeastern U.S. agricultural production areas and many other parts of the world, can readily transmit CDV in a nonpersistent manner $(13,20,49)$ and is documented to have been involved in some of the non-Brugmansia CDV outbreaks discussed above. However, there have been few reports of CDV in hosts other than Brugmansia and Datura spp., particularly within nursery and landscape settings frequented by the green peach aphid and known to contain CDV-infected Brugmansia and Datura spp. When considered along with the knowledge that CDV-infected Brugmansia can remain symptomless for extended periods of time and the potential selection of Brugmansia and CDV by humans in the Brugmansia center of origin, CDV does not appear to be a virus that will adversely affect the cultivation of Brugmansia and Datura spp. in the landscape.

Attention has been recently focused on solanaceous ornamentals as reservoir hosts for viruses and viroids that can infect other crops (45-47). This is not a novel concept, as Kahn and Monroe (21) nearly 40 years ago wrote that "wild or escaped arborescent $D a$ tura plants may act as reservoirs for viruses that infect solanaceous species." The truth of their statement was evidenced by the detection of CDV and three unidentified viruses in 57\% of Brugmansia samples imported as vegetative propagations from Colombia, Ecuador, or Bolivia and indexed at the U.S. Plant Quarantine Facility, Glenn Dale, MD between 1968 and 1978 (22). These same findings and sentiments were echoed by Lesemann and colleagues (26) 26 years later, noting that CDV infection was widespread in Brugmansia spp. from multiple sources in Germany and the Netherlands likely as "result of international exchange of this mainly vegetatively propagated ornamental between private, botanical and commercial collections." Propagation of virus- or viroid-infected Brugmansia plants and infection of stock plants and cuttings due to incomplete sanitation of pruning and propagation implements remain important potential sources of pathogens as exchanges and commercial sales increase, as known for other vegetatively propagated ornamental crops $(25,27)$. A broader survey of 
the natural host range and insect vectors of CDV is needed to fully assess its potential impact on regionally important agricultural crops and agricultural trade in the global economy. Stock plant indexing to eliminate CDV-infected plants from propagation schemes and/or tissue culture to produce virus-free plants should also be investigated to ascertain whether elimination of CDV from Brugmansia has any deleterious effects on the horticultural traits that have made Brugmansia so widely popular among botanists, gardeners, and plant collectors worldwide.

\section{Acknowledgments}

We thank Carrie Vanderspool, George Ingram, Heather Capobianco, and Jeff Smith for their excellent technical assistance, and Peggy Sieburth for providing Citrus exocortis viroid controls for Brugmansia viroid testing.

\section{Literature Cited}

1. ABADS. 2008. American Brugmansia and Datura Society, Register of Brugmansia cultivars and checklist of names in use - September 2008. http://www.abads.org

2. Adkins, S., Chellemi, D., Annamalai, M., and Baker, C. 2005. Colombian datura virus diagnosed in Brugmansia spp. in Florida. (Abstr.) Phytopathology $95: \mathrm{S} 2$.

3. Bailey, L. H., and Bailey, E. Z. 1976. Hortus Third. A Concise Dictionary of Plants Cultivated in the United States and Canada. Macmillan Pub. Co., Inc., New York.

4. Barclay, A. S. 1959. New considerations in an old genus: Datura. Botanical Museum Leaflets, Harvard University 18:245-272.

5. Berger, P. H., Adams, M. J., Barnett, O. W., Brunt, A. A., Hammond, J., Hill, J. H., Jordan, R. L., Kashiwazaki, S., Rybicki, E., Spence, N., Stenger, D. C., Ohki, S. T., Uyeda, I., van Zaayen, A., Valkonen, J., and Vetten, H. J. 2005. Virus Taxonomy - Classification and Nomenclature of Viruses, 8th Report of the ICTV. C. M. Fauquet, M. A. Mayo, J. Maniloff, U. Desselberger, and L. A. Ball, eds. Elsevier Academic Press, San Diego. pp. 819-841.

6. Brako, L., Rossman, A. Y., and Farr, D. F. 1995. Scientific and Common Names of 7,000 Vascular Plants in the United States. American Phytopathological Society, St. Paul, MN.

7. Bristol, M. L. 1969. Tree Datura drugs of the Colombian Sibunoy. Botanical Museum Leaflets, Harvard University 22:165-227.

8. Bristol, M. L., Evans, W. C., and Lampard, J. F. 1969. The alkaloids of the genus Datura, section Brugmansia Part. VI. Tree Datura Drugs (Datura candida cvs.) of the Colombian Sibundoy. Lloydia 32:123-130.

9. Chare, E. R., and Holmes, E. C. 2004. Selection pressures in the capsid genes of plant RNA viruses reflect mode of transmission. J. Gen. Virol. 85:3149-3157

10. Chen, J., Chen, J., and Adams, M. J. 2001. A universal PCR primer to detect members of the Potyviridae and its use to examine the taxonomic status of several members of the family. Arch. Virol. 146:757-766.

11. Christie, R. G., and Edwardson, J. R. 1994. Light and electron microscopy of plant virus inclusions. Monogr. 9, revised. University of Florida, Institute of Food and Agricultural Sciences, Gainesville.

12. Damsteegt, V. D., McDaniel, L. L., Evans, T. A., Durkin, S., and Maratos, M. 1996. Characterization of an exotic potyvirus isolated from Datura candida. (Abstr.) Phytopathology 86:S73.

13. Feldhoff, A., Wetzel, T., Peters, D., Kellner, R., and Krczal, G. 1998. Characterization of petunia flower mottle virus (PetFMV), a new potyvirus infecting Petunia $\times$ hybrida. Arch. Virol. 143:475-488.

14. Fraile, A., Escriu, F., Aranda, M. A., Malpica, J. M., Gibbs, A. J., and Garcia-Arenal, F. 1997. A century of tobamovirus evolution in an Australian population of Nicotiana glauca. J. Virol. 71:8316-8320.

15. Fry, C. R., Zimmerman, M. T., and Scott, S. W. 2004. Occurrence of Colombian datura virus in the terrestrial orchid, Spiranthes cernua. J. Phytopathol. 152:200-203.

16. Garcia-Arenal, F., Fraile, A., and Malpica, J. M. 2001. Variability and genetic structure of plant virus populations. Annu. Rev. Phytopathol. 39:157186.

17. Gibbs, A., and Mackenzie, A. 1997. A primer pair for amplifying part of the genome of all potyvirids by RT-PCR. J. Virol. Methods 63:9-16.

18. Gibbs, A. J., Fargette, D., García-Arenal, F., and Gibbs, M. J. 2010. Time the emerging dimension of plant virus studies. J. Gen. Virol. 91:13-22.

19. Ilmberger, N., Willingmann, P., Adam, G., and Heinze, C. 2007. A subgroup 1 Tobamovirus isolated from Brugmansia sp. and its detection by RT-PCR. J. Phytopathol. 155:326-332.

20. Kahn, R. P., and Bartels, R. 1968. The Colombian datura virus - a new virus in the Potato virus Y group. Phytopathology 58:587-592.

21. Kahn, R. P., and Monroe, R. L. 1970. Viruses isolated from arborescent Datura species from Bolivia, Ecuador, and Colombia. Plant Dis. Rep. 54:675-677.

22. Kahn, R. P., Waterworth, H. E., Gillaspie, A. G., Jr., Foster, J. A., Goheen, A. C., Monroe, R. L., Povich, W. L., Mock, R. G., Luhn, C. F., Calavan, E.
C., and Roistacher, C. N. 1979. Detection of viruses or viruslike agents in vegetatively propagated plant importations under quarantine in the United States, 1968-1978. Plant Dis. Rep. 63:775-779.

23. Kosakovsky Pond, S. L., and Frost, S. D. W. 2005. Datamonkey: Rapid detection of selective pressures on individual sites of codon alignments. Bioinformatics 21:2531-2533.

24. Kosakovsky Pond, S. L., and Frost, S. D. W. 2005. Not so different after all: A comparison of methods for detecting amino acid sites under selection. Mol. Biol. Evol. 22:1208-1222.

25. Lesemann, D.-E. 1996. Viruses recently detected in vegetatively propagated Petunia. Acta Hortic. 432:88-94

26. Lesemann, D.-E., Preissel, H.-G., and Verhoeven, J. Th. J. 1996. Detection of Colombian datura potyvirus and two unidentified potyviruses in Brugmansia hybrids. Acta Hortic. 432:346-353.

27. Lewandowski, D. J., Hayes, A. J., and Adkins, S. 2010. Surprising result from a search for effective disinfectants for Tobacco mosaic virus-contaminated tools. Plant Dis. 94:542-550.

28. Lockwood, T. E. 1973. Generic recognition of Brugmansia. Botanical Museum Leaflets, Harvard University 23:273-284

29. Lockwood, T. E. 1979. The ethnobotany of Brugmansia. J. Ethnopharmacol. 1:147-164.

30. Lucinda, N., Nagata, T., Inoue-Nagata, A. K., Salaroli, R. B., and Kitajima, E. W. 2008. Brugmansia suaveolens mottle virus, a novel potyvirus causing leaf mottling of Brugmansia suaveolens in Brazil. Arch. Virol. 153:19711976.

31. Nelson, M. R., Wheeler, R. E., and Zitter, T. A. 1982. Pepper mottle virus CMI/AAB Descriptions of Plant Viruses No. 253.

32. Preissel, U., and Preissel, H.-G. 2002. Brugmansia and Datura: Angel's Trumpets and Thorn Apples. Firefly Books, LTD, Stuttgart, Germany.

33. Rott, M., Schmidt, A.-M., Joshi, V., Masters, C., Godkin, S., and Johnson, R. 2009. First report of Colombian datura virus in Brugmansia in Canada. Plant Dis. 93:196.

34. Salamon, P., and Palkovics, L. 2005. Occurrence of Colombian datura virus in Brugmansia hybrids, Physalis peruviana L. and Solanum muricatum Ait. in Hungary. Acta Virol. 49:117-122.

35. Sambrook, J., and Russell, D. W. 2001. Molecular Cloning: A Laboratory Manual, 3rd ed. Cold Spring Harbor Laboratory, Cold Spring Harbor, NY.

36. Schubert, J., Doroszewska, T., Chrzanowska, M., and Sztangret-Wiśniewska, J. 2006. Natural infection of tobacco by Colombian Datura virus in Poland, Germany, and Hungary. J. Phytopathol. 154:343-348.

37. Shukla, D. D., and Ward, C. W. 1989. Structure of potyvirus coat proteins and its application in the taxonomy of the potyvirus group. Adv. Virus Res. 36:273-314.

38. Shultes, R. E. 1969. Hallucinogens of plant origin. Science 163:245-254.

39. Steele, V., and Thomas, J. E. 2009. First report of Colombian datura virus from Australia. Australas. Plant Dis. Notes 4:108-109.

40. Stenger, D. C., Seifers, D. L., and French, R. 2002. Patterns of polymorphisms in Wheat streak mosaic virus: Sequence space explored by a clade of closely related viral genotypes rivals that between the most divergent strains. Virology 302:58-70.

41. Strumpf, T., Buchhorn, R., and Lesemann, D. E. 2005. Auftreten des Colombian Datura virus an Tabak (Nicotiana tabacum cv. Virgin) im Freiland in Deutschland. Nachrichtenbl. Dtsch. Pflanzenschutzd. 57:1-3.

42. Tamura, K., Dudley, J., Nei, M., and Kumar, S. 2007. MEGA4: Molecular Evolutionary Genetics Analysis (MEGA) software version 4.0. Mol. Biol. Evol. 24:1596-1599.

43. Uscateguí, M. N. 1959. The present distribution of narcotics and stimulants amongst the Indian tribes of Colombia. Botanical Museum Leaflets, Harvard University 18:273-304.

44. U.S. Dep. Agric., NRCS. 2006. The PLANTS Database. National Plant Data Center, Baton Rouge, LA. Published online.

45. Verhoeven, J. Th. J., Jansen, C. C. C., Botermans, M., and Roenhorst, J. W. 2010. Epidemiological evidence that vegetatively propagated, solanaceous plant species act as sources of Potato spindle tuber viroid inoculum for tomato. Plant Pathol. 59:3-12.

46. Verhoeven, J. Th. J., Jansen, C. C. C., and Roenhorst, J. W. 2007. First report of pospiviroids infecting ornamentals in the Netherlands: Citrus exocortis viroid in Verbena sp., Potato spindle tuber viroid in Brugmansia suaveolens and Solanum jasminoides, and Tomato apical stunt viroid in Cestrum sp. Plant Pathol. 57:399.

47. Verhoeven, J. Th. J., Jansen, C. C. C., Roenhorst, J. W., Steyer, S., Schwind, N., and Wassenegger, M. 2008. First report of Solanum jasminoides infected by Citrus exocortis viroid in Germany and the Netherlands and Tomato apical stunt viroid in Belgium and Germany. Plant Dis. 92:973.

48. Verhoeven, J. Th. J., Jansen, C. C. C., Willemen, T. M., Kox, L. F. F., Owens, R. A., and Roenhorst, J. W. 2004. Natural infections of tomato by Citrus exocortis viroid, Columnea latent viroid, Potato spindle tuber viroid and Tomato chlorotic dwarf viroid. Eur. J. Plant Pathol. 110:823-831.

49. Verhoeven, J. Th. J., Lesemann, D.-E., and Roenhorst. J. W. 1996. First report of Colombian datura potyvirus in tomato. Eur. J. Plant Pathol. 102:895-898. 